\section{Alt om von Willebrands sykdom}

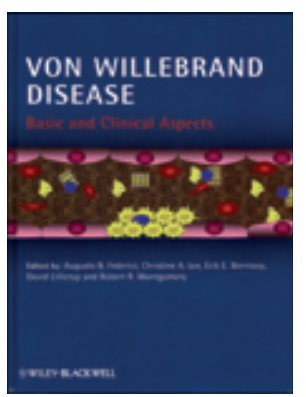

Augusto B. Federici, Christine A. Lee, Erik E. Berntorp et al, red. Von Willebrand disease

Basic and clinical aspects. $252 \mathrm{~s}$, tab, ill. Chichester: Wiley-Blackwell, 2011.

Pris GBP 80

ISBN 978-1-4051-9512-6

von Willebrands sykdom (VWD) har sitt navn etter den finske legen Erik Adolf von Willebrand (1870-1949), som første gang beskrev den i en artikkel på svensk (1). Han kalte sykdommen pseudohemofil, fordi den affiserte begge kjønn og forårsaket blødninger i ledd og muskler. von Willebrands sykdom forårsakes av kvantitative (VWD type 1 og type 3) eller kvalitative (VWD type 2A, 2B, 2N, 2M) endringer av von Willebrands faktor (VWF), et protein av varierende størrelse som syntetiseres av megakaryocytter (VWF finnes derfor i blodplater) og av endotelceller.

von Willebrands faktor har to viktige oppgaver i hemostasen. Den første er å feste blodplater til skadet årevegg og starte danning av hemostatisk plateplugg, den andre er å fungere som transportprotein for koagulasjonsfaktor VIII (hemofilifaktor A), viktig for danning av fibrin, som forsterker platepluggen. von Willebrands sykdom type 3 har symptomer som ved alvorlig hemofili og er sjelden (prevalens 1:1-5 millioner), type 1 og type $2 \mathrm{~A}$, derimot, er de vanligste årsaker (prevalens 1:1000-1 500) til spontan blødningstendens i hud og slimhinner samt ved traumer, kirurgi og fødsler. Dette er det viktig at alle leger kjenner til, slik at pasienten kan henvises for nærmere diagnostikk og behandling ved Koagulasjonslaboratoriet, Oslo universitetssykehus, Rikshospitalet, som har ansvar for diagnostikk og behandling av pasienter med von Willebrands sykdom.

Boken er skrevet av de fremste forskere på feltet. De har hatt en klar intensjon om å lage en samlet, oppdatert fremstilling og samtidig pietetsfullt gi historisk kreditt til pionerene. De har lyktes med begge deler. Den er fint innbundet, papirkvaliteten er god, og det er fine illustrasjoner og nyttige tabeller. Den gir en balansert og fullstendig fremstilling av dagens basale og kliniske kunnskap om sykdommen og vil derfor være verdifull for spesialister i hematologi og klinisk biokjemi. Siden det er kapitler om historikk, symptomer, diagnostikk, behandling og profylakse av von Willebrands sykdom, vil alle leger som kommer i kontakt med slike pasienter, ha stor nytte av den.

\section{Frank Brosstad}

Oslo

\footnotetext{
Litteratur

1. von Willebrand EA. Hereditär pseudohämofili. Finska Läkarsällskapets Handlingar 1926; 67: 87-112
}

\section{Oppdatert om maligne blodsykdommer}

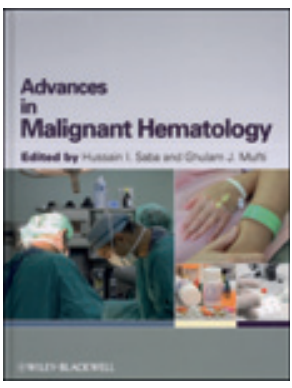

Hussain I. Saba, Ghulam Mufti, red. Advances in malignant hematology

437 s, tab, ill. Chichester: Wiley-Blackwell, 2011. Pris GBP 90

ISBN 978-1-4051-9626-0

Hvordan skal man holde seg oppdatert i faget sitt når kunnskapstilfanget øker stadig raskere? De fleste prøver å følge med i tidsskrifter og supplerer med å høre foredrag på nasjonale og internasjonale vitenskapelige møter. Daglige diskusjoner med kolleger i korridoren er også viktig! De store mursteinene av noen lærebøker er imidlertid i ferd med å utspille sin rolle. Det tar så lang tid å få dem ferdig at mye av stoffet er foreldet før utgivelsen finner sted.

Derfor var det med skepsis jeg åpnet denne boken om fremskritt innen malign hematologi. Men jeg ble gledelig overrasket. På bare 400 sider presenteres forskningsfronten innen akutte og kroniske leukemier, myeloproliferative sykdommer, lymfomer og plasmacellesykdommer. Den kom ut i 2011, og det er referanser fra så sent som 2010. Med hele 57 forfattere må kvaliteten nødvendigvis bli noe ujevn, men stort sett er kapitlene av høy kvalitet og kan bidra til å fylle kunnskapshullene så man føler seg oppdatert. Det er prisverdig at redaktørene (en engelsk og en amerikansk hematolog) har tatt med et kapittel om livskvalitet ved maligne blodsykdommer, men fremstillingen og referansene er selektive og preget av forfatternes interesser.

De få illustrasjonene - fotografier av blod- og beinmargsutstryk og beinmargshistologiske snitt - er ikke spesielt imponerende.

Mange av avsnittene om terapi er gode, med selvstendige og overordnede vurderinger fra forfatterne. Men mange er dessverre litt for mye preget av oppsummering av kliniske studier uten at forfatterne våger å stikke hodet frem og komme med helhetsvurderinger og begrunnede, personlige anbefalinger. Her og dessverre også for øvrig i hematologi og onkologi er det en tendens til ukritisk å godta surrogatendepunkter i randomiserte kliniske studier (respons, responsvarighet, progredieringsfri overlevelse), uten at nytteverdien av disse endepunktene for pasientene er dokumentert. Pasientene ønsker å bli kurert, sekundært å leve så lenge som mulig med best mulig livskvalitet. Bruker man andre endepunkter (surrogatendepunkter), bør man dokumentere at de har sammenheng med totaloverlevelse og livskvalitet.

Men, som sagt, Advances in malignant hematology kan gi en nyttig oppdatering av forskningsfronten innen maligne blodsykdommer - ikke bare for hematologer og spesialistkandidater, men også for den generelle indremedisiner (jeg håper de fortsatt finnes rundt om på sykehusene!).

Redaktørene har som mål å oppdatere boken innen tre år. Det er nok nødvendig - og jeg tror de klarer det.

Finn G.B. Wisløff

Det medisinske fakultet

Universitetet i Oslo 